\title{
UNIVERSITY OF MICHIGAN RADIOCARBON DATES $X$
}

\author{
H. R. CRANE and JAMES B. GRIFFIN
}

The University of Michigan, Ann Arbor, Michigan

The following is a list of dates obtained since the time of the compilation of List IX in December 1963. The method is essentially the same as that used for the work described in the previous list. Two $\mathrm{CO}_{2}-\mathrm{CS}_{2}$ Geiger counter systems were used. The equipment and counting techniques have been described elsewhere (Crane, 1961a, 1961h). The dates and estimates of error in this list follow the practice recommended by the International Radiocarbon Dating Conference of 1962, in that (a) dates are computed on the basis of the Libly half-life, $5570 \mathrm{yr}$. (b) A.D. 1950 is used as the zero of the age scale and (c) the errors quoted are the standard deviations obtained from the numbers of counts only. In previous Michigan date lists up to and including VII we have quoted errors at least twice as great as the statistical errors of counting, in order to take account of other errors in the over-all process. If the reader wishes to obtain a standard deviation figure which will allow ample room for the many other sources of error in the dating process, we suggest he double the figures that are given in this list.

We wish to acknowledge the help of Patricia Dahlstrom in preparing chemical samples and Roscoe Wilmeth and David M. Griffin in preparing the descriptions.

\section{SAMPLE DESCRIPTIONS}

\section{GEOLOGIC SAMPLES}

\section{M-1254. Smith Mastodon, Michigan}

$$
\begin{gathered}
10,700 \pm 400 \\
8750 \text { в.с. }
\end{gathered}
$$

Tooth (3rd molar) of American mastodon from Albert Smith farm $\left(43^{\circ}\right.$ $20^{\prime}$ N Lat, $84^{\circ} 36^{\prime} \mathrm{W}$ Long), Gratiot Co., Michigan, in SW $1 / 4$ NE $1 / 4$ Sec. 17, $\mathrm{T} 11 \mathrm{~N}, \mathrm{R} 2 \mathrm{~W}$. lying on gravelly bed, covered by marl, in turn covered by $2 \mathrm{ft}$ of vegetable deposits. Bones scattered; show signs of water action (MacCurdy, 1919 , p. 110). Pollen analysis of sediments in alveolar cavities completed. Date important in time-stratigraphic correlation of late-glacial vegetation of central Michigan (Skeels, 1962, p. 111; Oltz and Kapp, 1963, p. 343-345). Coll. 1909; subm. by R. O. Kapp, Alma College, Alma, Michigan. Comment (R.O.K.) : pollen analysis and study of macrofossils establish presence of late-glacial spruce-pine forests in central Michigan at this date. Site lies just outside beach ridges of Lake Saginaw, presumably near high-water strandline of post-Valders Great Lakes; these beaches extend nearly to the site at the time of the death of the mastodon. Local habitat included disturbed sites which favored growth of Artemisia, Ambrosia, and Eleagnus (latter considered late-glacial indicator species).

\section{M-1400. Prillwitz Mammoth, Michigan}

Cross-section of tusk of nearly complete specimen of Mammuthus jeffersoni from Berrien Springs $\left(41^{\circ} 48^{\prime} 30^{\prime \prime} \mathrm{N}\right.$ Lat, $86^{\circ} 29^{\prime} \mathrm{W}$ Long), Berrien Co., 
Michigan, in Sec. 5, T $6 \mathrm{~S}, \mathrm{R} 17 \mathrm{~W}, 0.3 \mathrm{mi} \mathrm{W}$ of corner of Hotchberber and River Roads, ca. $100 \mathrm{ft} \mathrm{S}$ of road along edge of pond. 4 to $10 \mathrm{ft}$ below surface, in muck overlain by sand. Coll. 1962 by W. G. Melton; subm. by C. W. Hibbard, Univ. of Michigan. Comment (C.W.H.) : as tusk was taken directly from muck, recent contamination is improbable. Date is well within range of that of American mastodon from region.

\section{M-1571. Lake Chippewa Low Stage, Michigan}

$7400 \pm 500$

$\mathbf{5 4 5 0}$ в.c.

Pisidium shells (Sample X-B46-5) from Lake Chippewa low-water stage ( $43^{\circ} 10^{\prime} \mathrm{N}$ Lat, $86^{\circ} 50^{\prime} \mathrm{W}$ Long), in Lake Michigan, W of Muskegon. From zone of shells and sand 5 to $10 \mathrm{~cm}$ below lake bottom beneath $340 \mathrm{ft}$ of water. Shell zone presumably represents Chippewa low-water zone, though not at typical 1 to $2 \mathrm{~m}$ depth. Zone includes its immediately underlying unconformity, which truncates underlying layers. Chippewa stage sediment is post-Algonquin (ca. 10,000 yr B.P.) and pre-Nipissing (ca. 4000 yr B.P.) (Hough, 1955, 1958). Coll. 1963; subm. by J. L. Hough, Univ. of Michigan. Comment (J.L.H.) : topographical position of station, low on slope of a submerged mid-lake topographic high, accounts for small amount of post-low stage sediment covering the shells. Several bottom samples, some including dead Pisidium shells from the topographic high, indicate that present bottom is at or close to the Chippewa-Stanley land surface and that there has been little sedimentation since its submergence following the low stage.

\section{M-1516. Warren Beach Ridge, Ohio $\quad 4290 \pm 150$$$
2340 \text { в.c. }
$$

Bone (Platygonus compressus) $\left(41^{\circ} 22^{\prime} \mathrm{N}\right.$ Lat, $83^{\circ} 14^{\prime} \mathrm{W}$ Long), Sandusky Co., Ohio, $5 \mathrm{mi}$ W of Fremont, in SW 1/4 Sec. 27, T 5 N, R 14 E, Washington Twp., at depth of ca. $15 \mathrm{ft}$ below top of sand ridge, possibly a dune, that forms part of Lake Warren Beach Ridge (Hoare et al., 1964). Coll. 1962 by C. Innis and T. Hole; subm. by R. D. Hoare, Bowling Green State Univ. Comment (R.D.H.) : date is about half that expected on basis of other dates from Warren Beach Ridge in this area. Dr. J. L. Forsyth, Ohio Geol. Survey, suggests that heaping up of Lake Warren beach sands into dunes may postdate the lake, and also that date may reflect unreliability of bone samples (personal commun.).

\section{M-1518. Clyde, Ohio}

$$
\begin{array}{r}
150 \\
\text { A.D. } 1800
\end{array}
$$

Bone (Bison or Bos) from Clyde $\left(41^{\circ} 20^{\prime} \mathrm{N}\right.$ Lat, $82^{\circ} 54^{\prime} \mathrm{W}$ Long). Sandusky Co., Ohio, at depth of 4 to $6 \mathrm{ft}$ in Lake Warren beach ridge on $\mathrm{S}$ side of State Road 101, ca. 41/2 mi NE of Clyde, in NW 1/4 NE 1/4 Sec. 4, T 4 N, R 17 E, York Twp. Coll. 1962 by C. Innis and T. Hole; subm. by R. D. Hoare. Comment (R.D.H.) : date suggests Bos rather than Bison. Unfortunately site nearly destroyed and stratigraphic relationships could not be determined.

\section{M-1568. Teels Marsh, Nevada}

$$
10,760 \pm 400
$$$$
8810 \text { в.C. }
$$

Gaylussite from Teels Marsh, a playa $\left(38^{\circ} 12^{\prime} 30^{\prime \prime} \mathrm{N}\right.$ Lat, $118^{\circ} 20^{\prime} 20^{\prime \prime} \mathrm{W}$ Long), W Nevada, from Drill Hole 3 in center of marsh, at SW 1/4 NW 1/4 
T 4. N, R 33 E. From depth $18 \mathrm{ft}$, from late Pleistocene or recent lacustrine clays which grade abruptly into playa clays at $10 \mathrm{ft}$ depth. Should help date sedimentation rate, age of pluvial-postpluvial transition, vegetational history to he obtained from pollen analysis, and age of the most recent series of eruptions of Mono Craters, California, represented by ash layers above the gaylussite. Coll. 1963; subm. by R. L. Hay, Univ. of California.

II. ARCHAEOLOGICAL SAMPLES

\section{A. Upper Mississippi Valley and Great Lakes}

\section{Price Site series, Wisconsin}

Charred hickory nuts, charcoal, and bone from Price Sites I, II, and III $\left(43^{\circ} 11^{\prime} \mathrm{N}\right.$ Lat, $90^{\circ} 40^{\prime} \mathrm{W}$ Long), NW 1/4. NW 1/4 Sec. 7, T $8 \mathrm{~N}, \mathrm{R} 2 \mathrm{~W}$, Richland Co., Wisconsin. Price Sites I and II are adjacent villages which are respectively Early Woodland and Hopewell. Price Site III is a burial ground adjacent to village and associated with them. Coll. 1960-1961 and subm. by Joan Freeman, State Hist. Soc. of Wisconsin.

\section{M-1436. Price Site I, Feature 48}

Charred hickory nuts and charcoal from Feature 48.

\section{M-1437. Price Site II, Feature 16}

$$
\begin{gathered}
1650 \pm 100 \\
\text { A.D. } 300 \\
1860 \pm 100 \\
90 \text { в.c. }
\end{gathered}
$$

Charred hickory nuts from Feature 16, which contained a side-notched point of a type associated with Early Woodland and Early Hopewell pottery at the sites.

\section{M-1438. Price Site III, Feature 15}

$200 \pm 100$ A.D. 1750

Charcoal from Feature 15, a pit with fire-hardened clay walls.

\section{M-1439. Price III, Feature 17}

$450 \pm 100$

\section{A.D. 1500}

Charcoal from Feature 17, a pit containing burned human bone and an unburned human long bone fragment. A Price Stemmed point was associated with the bones.

M-1440. Price Site III, Feature 10

$4180 \pm 150$ 2230 B.C.

Charcoal from Feature 10, $3.91 \mathrm{ft}$ below surface. Immediately above Burial 3 of this feature.

\section{M-1441. Price Site III, Feature 10, Burial $3 \quad 3620 \pm 150$}

Bone from Feature 10, Burial 3, $3.95 \mathrm{ft}$ below surface. Covered with red ochre.

M-1442. Price Site III, Feature 25, Burial 4

$3280 \pm 150$

1330 в.C.

Bone from Feature 25, Burial 4, $1.3 \mathrm{ft}$ below surface. Feature 25 is a large pit containing 8 levels of burials. 


\section{M-1443. Price Site III, Feature 25, Burial 22}

Bone from Feature 25, Burial 22, $2.0 \mathrm{ft}$ below surface.

\section{M-1444. Price Site III, Feature 25, Burial 31f $\quad 3710 \pm 150$ \\ 1760 в.с.}

Bone from Feature 25, Burial 31f, $2.7 \mathrm{ft}$ below surface. Drilled bear canine associated.

\section{M-1445. Price Site III, Feature 21}

$$
\begin{aligned}
& 2920 \pm 130 \\
& 970 \text { в.с. }
\end{aligned}
$$

Bone from Feature 21, burial $1.3 \mathrm{ft}$ below surface. General Comment (J.F.) : M-1438 and M-1439 do not date occupation of Price Site III. M-1436 and M-1437 date Hopewell occupation of Price Sites I and II, the village sites. We lack good Early Woodland dates from the village sites to tie in with the earlier burials at Price Site III.

\section{Isle Royale, Minong Ridge series, Michigan}

Charcoal and wood from aboriginal copper mines and tailing piles on Minong Ridge in Isle Royale Natl. Park, Keweenaw Co., Michigan. Will help establish time span of mining activity. Excavations of mines on Isle Royale have been described recently by Bastian in a manuscript submitted to the National Park Service in 1963, and older excavations are presented in Griffin (1961). Coll. 1962 and subm. by Tyler Bastian for Mus. of Anthropol., Univ. of Michigan.

\section{M-1384. Isle Royale, Minong site ( 20 IR 24) $\quad 4420 \pm 150$}

Charcoal from Exploratory Trench $2\left(48^{\circ} 04^{\prime} 56^{\prime \prime} \mathrm{N}\right.$ Lat, $88^{\circ} 43^{\prime} 54^{\prime \prime} \mathrm{W}$ Long), on SE slope of Minong Ridge near McCargoe Cove, 5.0 to $5.5 \mathrm{ft}$ deep in apparently undisturbed tailing deposit, so should date mining activity. Hammerstones were only artifacts found.

\section{M-1390. Isle Royale, Minong site (20 IR 24) $\quad 4400 \pm 150$}

Charcoal from Exploratory Trench $4\left(48^{\circ} 04^{\prime} 56^{\prime \prime}\right.$ N Lat, $88^{\circ} 43^{\prime} 50^{\prime \prime}$ W Long), on SE slope of Minong Ridge near McCargoe Cove, from various places in fill from 2.6 to $6.8 \mathrm{ft}$ below surface. Most of the fill, including sand, gravel. cobbles, boulders, and a few tailings and hammerstones, was unconsolidated overburden which had been removed by Indians to reach copper-bearing bedrock. Should date mining activity, probably at about same time as M-1384.

\section{M-1387. Isle Royale, Minong site (20 IR 24), $\quad 3220 \pm 130$ Pit 77 \\ 1370 в.c.}

Charcoal from Pit $77\left(48^{\circ} 05^{\prime} 23^{\prime \prime}\right.$ N Lat, $88^{\circ} 42^{\prime} 27^{\prime \prime}$ W Long), near E end of Minong Ridge on McCargoe Cove, from thin dark stratum underlying a sterile, hard, horizontal stratum of apparently water-laid sand and fine gravel which transected tailing deposit $4.3 \mathrm{ft}$ below surface. Horizontal stratum of sand and gravel may be result of surface wash or a temporary rise in level of Lake Superior (Nipissing Stage). Should date mining activity. 
M-1388. Isle Royale, Minong site (20 IR 24)

$3460 \pm 130$

1510 в.c.

Charcoal from Pit 77 above horizontal stratum of sand and fine gravel, from various places among tailings between $3.0 \mathrm{ft}$ below surface and top of sand stratum at $4.3 \mathrm{ft}$ below surface. Large size of some hammerstones in fill distinguishes mine from others excavated at Isle Royale. Should date mining. activity, and indicate whether types of hammerstones may have chronological significance.

\section{M-1389. Isle Royale, Minong site (20 IR 24) $\quad 3310 \pm 130$}

Charcoal from Pit 74 ( $48^{\circ} 05^{\prime} 24^{\prime \prime} \mathrm{N}$ Lat, $88^{\circ} 42^{\prime} 23^{\prime \prime} \mathrm{W}$ Long), at $\mathrm{E}$ end of Minong Ridge on McCargoe Cove, ca. $15 \mathrm{ft}$ above Lake Superior. Mine is ca. $2.5 \mathrm{ft}$ deep and was filled to within $0.5 \mathrm{ft}$ from top with tailings, organic material, and a few hammerstones. Sample from small area ca. $1.5 \mathrm{ft}$ below surface of fill. Should provide minimum date for abandonment of mine. Mine is ca. $5 \mathrm{ft}$ below estimated level of Algoma Stage on Isle Royale, so should postdate the estimated 3200 в.P. age of Algoma (Farrand, 1960; table 4, pl. 2 ).

\section{M-1385. Isle Royale, Minong site ( 20 IR 24) $\quad 3360 \pm 130$ Pit 76 \\ 1410 в.с.}

Wood, Pincus banksiana and Picea (probably glauca) (id. by M. J. Black), from Pit $76\left(48^{\circ} 04^{\prime} 59^{\prime \prime} \mathrm{N}\right.$ Lat, $88^{\circ} 43^{\prime} 57^{\prime \prime} \mathrm{W}$ Long $)$, near top of NW side of Minong Ridge near McCargoe Cove. Measured from lowest edge, mine is $8.5 \mathrm{ft}$ deep and was filled by natural causes to within $1.5 \mathrm{ft}$ of top with organic material, some tailings, and a few hammerstones. Sample from lowest level of organic fill, 0.3 to $0.8 \mathrm{ft}$ from the bottom. Should provide minimum date for abandonment of mine.

General Comment (T.B.) : with one exception, all of the dated mining activity clusters at either end of a range from ca. 2200 B.c. to 1300 B.C., essentially in agreement with peak period of Old Copper culture as estimated by J. B. Griffin (1961) and others. Lack of evidence for mining during Hopewell period, as well as before 2500 B.c., may be due to vagaries of sampling, and perhaps could be clarified by excavation of mines elsewhere in Lake Superior region. However, with so many dates available, there is justification for tentatively accepting them at face value. Lookout site, dated at approx. A.D. 1600 (this list, sample M-1276), supports contention that some aboriginal mining occurred in the protohistoric period. No significant chronological differences apparent among the various kinds of hammerstones on Isle Royale. Date on Pit 74, (M-1389) is not consistent with estimated age and/or level of Algoma Stage of Lake Superior at Isle Royale.

\section{M-1272. Chippewa Harbor I site ( 20 IR 1), $\quad 840 \pm 100$ Michigan \\ A.D. 890}

Small pieces of charcoal from Chippewa Harbor I site $\left(48^{\circ} 2^{\prime} \mathrm{N}\right.$ Lat, $88^{\circ}$ 39' W Long), N side of Chippewa Harbor, Isle Royale Natl. Park, Keweenaw Co., Michigan, scattered through fill in Test 2, Level 3, 1 to $2 \mathrm{ft}$ below surface in mottled sand. Middle and Late Woodland artifacts. Coll. July 1960 and subm. 
by Tyler Bastian for Mus. of Anthropol., Univ. of Michigan. Comment (T.B.) : dates part of Late woodland occupations.

\section{M-1274. Finn Point site (20 IR 5), Michigan \\ $3060 \pm 130$ 1100 B.C.}

Charcoal from Finn Point site (47 $56^{\prime} \mathrm{N}$ Lat, $88^{\circ} 561 / 2^{\prime}$ W Long), NW side of Hay Bay, Isle Royale Natl. Park, Keweenaw Co., Michigan. From Test 7, Feature 2, a cooking pit ca. $1.5 \mathrm{ft}$ in diam and $0.6 \mathrm{ft}$ deep, on terrace $5.2 \mathrm{ft}$ above Lake Superior. Top of feature ca. $0.5 \mathrm{ft}$ below surface. No diagnostic artifacts in direct association, but Late Woodland artifacts near top of feature. All other known artifacts from site are Middle or Late Woodland. Coll. July 1960 and subm. by Tyler Bastian. Comment (T.B.) : indicates site may have been occupied during period of copper mining activity, perhaps by miners who worked the nearby Siskiwit site (20 IR 6). Also suggests that Lake Superior stood near its present level in Hay Bay shortly after Algoma Stage (approx. 3200 B.P.).

\section{M-1386. Isle Royale, Siskiwit site (20 IR 6) Pit $66 \quad 3370 \pm 130$}

Charcoal from Pit 66 ( $48^{\circ} 06^{\prime} 30^{\prime \prime} \mathrm{N}$ Lat, $88^{\circ} 33^{\prime} 31^{\prime \prime}$ W Long), on NW side of Rock Harbor across from East Caribou Island. Mine is distinguished from others excavated on Isle Royale because several hammerstones are partly grooved and unusually small. Should provide minimum date for abandonment of mine.

\section{M-1276a. Lookout site, Michigan}

$325 \pm 100$

\section{M-1276b. Lookout site, Michigan (rerun)}

Birch logs from aboriginal copper mine at Lookout site $\left(48^{\circ} 9^{\prime} 43^{\prime \prime} \mathrm{N}\right.$ Lat, $88^{\circ} 29^{\prime} 6^{\prime \prime}$ W Long), ca. $225 \mathrm{ft}$ above Lake Superior, on Greenstone Ridge near Monument Rock, Isle Royale, Keweenaw Co., Michigan. Top of specimens $5.1 \mathrm{ft}$ below top of fill and $1.1 \mathrm{ft}$ from bottom of Pit 4, $8.3 \mathrm{ft}$ deep. Mine in an area where at least one prehistoric mine was cleared of its fill about 1849 (Foster and Whitney, 1850, p. 162), but surface features suggest that Pit 4 was undisturbed. Fill assumed to have accumulated after mine abandoned (Bastian, 1963). Coll. 1960 by J. Staiger and P. Roper; subm. by Tyler Bastian. Comment (T.B.) : small size of logs and their nearness to bottom of mine suggests dates of samples approx. that of the mine. Dates imply that aboriginal copper mining persisted in Lake Superior region until introduction of Euro-American metals early in 17th century.

\section{Juntunen series, Michigan}

Charcoal and human bone from Juntunen site (20 Mk 1), $\left(45^{\circ} 49^{\prime} \mathrm{N}\right.$ Lat, $84^{\circ} 35^{\prime} \mathrm{W}$ Long), Bois Blanc Island, Mackinac Co., Michigan. Subm. by A. McPherron, for Mus. of Anthropol., Univ. of Michigan.

\section{M-1391. Juntunen site, Feature 20}

$620 \pm 100$

\section{A.D. 1330}

Charcoal from F-20, an undisturbed horizontal concentration of sherds with considerable amounts of fish bone, scales, and charcoal. Coll. 1961 by 
G. R. Peske. Pottery is of the collared, castellated, push-and-pull decorated variety pertaining to one of the latest occupations of the site, and is illustrated in McPherron (1963, fig. 1, E). Feature was evidently a casual dump for used and broken vessels and other kitchen debris, trampled flat soon after deposition.

\section{M-1392. Juntunen site, Feature 45}

$1900 \pm 120$

Uncharred human bone (ribs and extremities) from Burial 5 of F-45, an ossuary which yielded a beaver incisor hafted in deer antler, a cut bear jaw, and lanceolate bifaces - all but the first in association suggesting enclosure in a bag. Sherds with dentate stamping, and parts of a conical-based plainsurfaced vessel with a simple incised design, were also recovered. Coll. 1962 by C. Eyman. Ossuary described in Bettarel and Harrison (1962).

General Comment (A.M.): M-1392 places Middle Woodland occupation at early date. No close similarities to the pottery are known. No evidence for occupation of site between this time period and that of Late Woodland deposits, dating ca. A.D. 800-1300 (M-1392; also M-1140, M-1141, M-1142, Michigan VI). M-1391 is almost exactly coeval with a date on another ossuary (Feature 11, A.D. 1320: M-1188, Michigan VIII).

\section{M-1401. Holcombe site (20 MB 30), Michigan $\quad 3580 \pm 200$}

Charcoal (Fagus granditolia, Quercus borealis, Quercus alba) from Holcombe site $183^{\circ} 00^{\prime} \mathrm{N}$ Lat, $42^{\circ} 30^{\prime} \mathrm{W}$ Long), Macomb Co., Michigan. From Feature 3, Sq. 620-500, interpreted as a fire pit with no apparent modern disturbance and containing charcoal and some flint debris. Expected to date a concentration of Early Archaic artifacts, as well as Feature No. 2, a pit containing caribou bone which is associated with the concentration. Sample could also date the Lake Algonquin beach upon which site is located (see Fitting, 1964; Cleland, 1965). Coll. 1961 by D. W. Taggart; subm. by Charles Cleland for Mus. of Anthropol., Univ. of Michigan. Comment (C.C.) : dates neither Early Archaic occupation nor Lake Algonquin beach with which it is associated. Since Feature 2 dates from Early Archaic occupation, there is no temporal relationship between this feature and Feature 3.

\section{Spoonville series, Michigan}

Charred wood from Spoonville site (20-0T-1), $\left(43^{\circ} 3^{\prime} \mathrm{N}\right.$ Lat, $86^{\circ} 3^{\prime} \mathrm{W}$ Long), Ottawa Co., Michigan. Coll. 1962 by R. Bettarel and S. Harrison; subm. by R. E. Flanders, Grand Valley College, Allendale, Michigan.

\section{M-1427. Spoonville site, Test Pit 11}

$1735 \pm 110$

\section{A.D. 215}

Charred wood from Test Pit 11, Feature 3, depth 1.5 to $2.5 \mathrm{ft}$ below surface. Feature 3 is a trash pit with mussel shell, animal bone, charred wood, grit-tempered smoothed sherds. Some root intrusion in pit but it is hoped that sample dates Middle Woodland level.

\section{M-1428. Spoonville site, Test Pit 18}

$1840 \pm 120$

\section{A.D. 110}

Charred wood from Test Pit 18, depth $8 \mathrm{ft}$ below surface. Associated with 1 crude corner-notched point; grit-tempered ceramics, mostly cord-marked, 
some smoothed; 1 straight rim with boss, partially smoothed horizontal incising; fragment of smoothed clay pipe bowl.

General Comment (R.E.F.) : dates seem satisfactory.

M-1431. Verchave II Site (20 Mb 181), Michigan ${ }_{\text {A.D. }} \mathbf{8 6 5} \pm 100$

Charcoal from Verchave II site, $20 \mathrm{Mb} 181\left(42^{\circ} 36^{\prime} \mathrm{N}\right.$ Lat, $82^{\circ} 51^{\prime} \mathrm{W}$ Long), Macomb Co., Michigan, in T 2 N, R 14 E, Harrison Twp., 13/4 mi E of Mt. Clemens, along bank of Clinton River. From Feature 2, 300 E 200, base of a large deep straight-sided storage pit of Late Woodland age, with bottom layer of stratified refuse fill consisting of thick layer of yellow-walleye bones, followed by numerous charred hickory nuts, more fish bones, corn kernel, fragments of base of large round-bottom exterior cord-marked vessel, and several rim sherds of another Late Woodland vessel. Pit lies below 1830-1840 American occupation. Associated vegetal material includes charred hickory nuts, walnut, grape seeds, hawthorn wood, acorn, hazelnut, and corn (Yarnell, 1964; Fitting, 1965). Coll. 1962 and subm. by D. W. Taggart, Univ. of Michigan. Comment (D.W.T.) : acceptable date for this horticultural Late Woodland occupation of eastern Michigan, with large deep storage pits.

\section{M-1432. Green Point site (20 SA-1), Michigan $\quad 2480 \pm 120$}

Charcoal from Green Point site (20 SA-1), $\left(43^{\circ} 23^{\prime} \mathrm{N}\right.$ Lat, $83^{\circ} 58^{\prime} \mathrm{W}$ Long), Saginaw Co., Michigan, in S 1/2 NW 1/4 Sec. 2, T 11 N, R 4 E. Feature 6 (305 E 650, Sheet 8-9), at depth of ca. $6.5 \mathrm{ft}$. Occupation bounded above and below by stiff gray lacustrine clay. Stratigraphically well below scanty Middle Woodland occupation at roughly $3 \mathrm{ft}$ depth. Earliest occupation at site, associated with probable butt of plano-convex adze and small side-notched point made from Saginaw-variety blanks like those recovered from Pomranky burial near Midland, Michigan, where turkey-tail blades were associated. Associated vegetal materials include two cucurbit seeds, cherry or hackberry seeds, hickory nut, a hazel or beechnut shell, hazelnut, and one acorn meat (Wright, 1964). Coll. 1962; subm. by D. W. Taggart. Comment (D.W.T.) : although a somewhat earlier temporal position was anticipated because of depth and geological context of scanty occupation, as well as its cultural affiliation with the presumed Late Archaic Pomranky burial (Binford, 1963), and apparent lack of ceramics in the occupation, date now seems acceptable for Schultz component at the site (with Marion Thick pottery and ground-stemmed points) and terminal phase of Pomranky Complex.

\section{M-1507. Site Cile-1, Ontario, Canada}

$$
\begin{array}{r}
1630 \\
\text { A.D. } 320
\end{array}
$$

Charcoal (NMC-5) from Site Cile-l $\left(47^{\circ} 26^{\prime} \mathrm{N}\right.$ Lat, $84^{\circ} 44^{\prime}$ Long), Ontario, on W bank of Sand River at its mouth (Lake Superior). From undisturbed hearth (Feature I with associated ceramics and stone artifacts) in a band 1 to 3 in. thick, 5 in. below exposed surface (original depth of overburden unknown, site exposed by highway construction). Site is single small component of Laurel Tradition. Analysis of Donaldson site (Wright and Anderson, 1963), with approx. date of 500 B.c., revealed presence of small 
sample Laurel Tradition ceramics and suggests Laurel much earlier than previously believed. Extension of time depth of this western complex has critical bearing on problem of Middle Woodland origins. Date in excess of 500 B.C. would greatly clarify its relationship to eastern Middle and Early Woodland complexes. Estimated date 500 to 800 B.c. Coll. 1963. Subm. by J. V. Wright, Natl. Mus. of Canada. Comment (J.V.W.) : at time of above age estimate, analysis of Laurel components in Northern Ontario was incomplete. The now completed seriations indicate that Cile-1 site is late and in light of new data later date is acceptable. Other $\mathrm{C}^{14}$ dates on Laurel and related Middle Woodland complexes suggest that an extensive time range is involved in the Laurel Tradition and that change was very gradual.

\section{M-1435. Feehely site (20 SA 128), Michigan}

$1695 \pm 120$

Charcoal (Platanus occidentalis, id. by V. H. Jones) from Feehely site (20 SA 128) $\left(43^{\circ} 23^{\prime}\right.$ N Lat, 84 $4^{\circ} 03^{\prime}$ W Long), Saginaw Co., Michigan, in Center SE 1/4 Sec. 1, T 11 N, R 4 E, Swan Creek Twp. Sand knoll, elev. 605 ft. From Feature N, 60-130, Sheet 2, at $605.3 \mathrm{ft}$ elev. (A. T.), at depth of 9 to $1.1 \mathrm{ft}$ below surface, slightly below plow zone in upper levels of dune formation. Feature $\mathrm{N}$ is small fire-pit, with slightly baked margins, adjacent to and apparently contemporaneous with Burial 4, apparently flexed and associated with a copper awl and profuse red ochre. Charcoal stratigraphically later than earliest burials on site and should be somewhat later than M-1139, dated at $3930 \pm 300 \mathrm{yr}$ ago (Michigan VII, p. 186). Should date terminus of this Late Archaic "Glacial Kame-like" burial complex. Coll. 1960. Subm. by D. W. Taggart. Comment (D.W.T.) : date perplexing as the charcoal was obtained from almost the only clear fire pit on this virtually single-component nonceramic site. Charcoal was in dense, though small, concentration, and should represent a unitary unmixed feature. Perhaps the near surface location in porous soil allowed considerable contamination by roots and humic acids.

\section{M-1556. Fort Michilimackinac, Michigan}

$225 \pm 100$

\section{A.D. 1725}

Proximal end of tibia of Alces americana (id. by Charles Cleland) from Fort Michilimackinac ( $45^{\circ} 48^{\prime} \mathrm{N}$ Lat, $84^{\circ} 45^{\prime} \mathrm{W}$ Long), Mackinac City, Emmet Co., Michigan. From Feature 71 , a refuse pit in basement of a French house (Maxwell and Binford, 1961). Feature 71 given estimated date of A.D. 1740 by Binford. Coll. 1961, by Lewis Binford; subm. by M. S. Maxwell, Michigan State Univ. Tested as check sample for bone of known age. Comment (J.B.G.) : as good as can be expected.

\section{M-1487. Snyders site, Illinois}

$1850 \pm 120$

\section{A.D. 50}

Charcoal (Acc. No. 3467B) from Snyders site $\left(39^{\circ} 04^{\prime} 10^{\prime \prime} \mathrm{N}\right.$ Lat, $90^{\circ} 40^{\prime}$ 16" W Long), Calhoun Co., Illinois, in NW 1/4 Sec. 32, T 12 S, R 2 W. From Pit No. 18, Sec. B, Feature C, a cache pit. Typical Snyders site complex. Coll. 1947 by J. Witthoft; subm. by J. B. Griffin. Comment (J.B.G.) : date is satisfactory. 


\section{M-1096. Phipps site, Iowa}

Charcoal from Phipps site ( $42^{\circ} 48.3^{\prime} \mathrm{N}$ Lat, $95^{\circ} 33.5^{\prime} \mathrm{W}$ Long $)$, Cherokee County, Iowa, from SW 9A, from the 84 to 90 in. level, one of the lowest levels of the type site of the Mill Creek Aspect. Should give base date for this NW Iowa derivative of Old Village tradition of Cahokia. Coll. 1956 and subm. by R. J. Ruppe, Arizona State Univ., Tempe. Comment (R.J.R.) : it seems to me that basal Mill Creek levels may date earlier than A.D. 1000, but this cannot be documented. Because of amount of disturbance caused by later house building, level from which sample was procured may not be as early as I thought.

\section{B. Lower Mississippi Valley and Southeast}

\section{M-1090. Davis site, Oklahoma}

$$
\begin{array}{r}
250 \\
\text { A.D. } 1700
\end{array}
$$

Wooden post from Davis site $\left(34^{\circ} 04^{\prime} \mathrm{N}\right.$ Lat, $94^{\circ} 55^{\prime} \mathrm{W}$ Long $)$, McCurtain Co., Oklahoma. From a circular house pattern, Location Mc-6, Area A, Sq. 0-N14. Site is McCurtain Focus according to the pottery (Avery Engraved, Nash Neckbanded, and La Rue) and is certainly Fulton Aspect. House circular with two rings of posts, one of larger posts on the interior and one of smaller posts on the exterior. Identical in construction plan to the Wichita grass houses, such as those at Indian City, Anadarko. Coll. 1955 and subm. by R. E. Bell, Univ. of Oklahoma. Comment (R.E.B.) : date is too late for this site (Wilson, 1962). Archaeological evidence does not suggest that post is intrusive at the site, although this is a possibility.

\section{M-1091. Mouse site, Oklahoma \\ $1000 \pm 100$ A.D. 950}

Charcoal from Mouse site ( $35^{\circ} 30^{\prime} \mathrm{N}$ Lat, $99^{\circ} 14^{\prime} \mathrm{W}$ Long), Custer Co., Oklahoma. From Feature 19, a refuse or storage pit. Site assigned to Custer Focus (Buck, 1959). Coll. 1957 and subm. by R. E. Bell, Univ. of Oklahoma. Comment (R.E.B.) : this should date Custer Focus for western Oklahoma. Supports Buck's conclusion (1959) that Mouse site is early within Custer Focus.

\section{Harlan series, Oklahoma}

Charcoal from Harlan site ( $35^{\circ} 55^{\prime} \mathrm{N}$ Lat, $95^{\circ} 14^{\prime} \mathrm{W}$ Long), Cherokee Co., Oklahoma. From Unit 7, a mound assigned to Gibson Aspect (Bell, 1949). Should give range for the mound and hence probably date the site, excluding an Archaic component. Coll. 1958. Subm. by R. E. Bell.

\section{M-1092. Harlan site, Mound A $1090 \pm 100$ A.D. 860} mound.

Charcoal from fill of Mound A, the period of final construction at the

\section{M-1093. Harlan site, House Area}

$$
\begin{array}{r}
1360 \pm 100 \\
\text { A.D. } 590
\end{array}
$$

Charcoal from within house post pattern found on original surface below four stages of mound construction. Should be oldest sample from Unit 7 . 


\section{M-1094. Harlan site, Mound B}

Charcoal from fill of Mound B, third construction unit of mound. General Comment (R.E.B.) : dates agree well with other samples from Harlan site (Miller, 1963), although M-1092 (Mound A) and M-1094 (Mound B) appear to be reversed. Mound B underlies Mound A and should give an older date.

\section{Stanfield-Worley bluff shelter $\left(\mathrm{Ct}^{\mathrm{c}} 125\right)$ series, Alabama}

Plant rharcoal from Stanfield-Worlev bluff shelter. $\mathrm{Ct}^{\mathrm{c}} 125$ (34 $34^{\circ} 15^{\prime \prime}$ 


\section{Stallings Island series, Georgia}

Charcoal and charred plant remains from Stallings Island $\left(33^{\circ} 32^{\prime} \mathrm{N}\right.$ Lat, $82^{\circ} 02^{\prime}$ W Long) in Savannah River, 8 mi above Augusta, Georgia. Coll. 1961 by H. B. Greene; subm. by R. P. Bullen, Florida State Mus.

\section{M-1277. Stallings Island, Pit 2}

$4450 \pm 150$

Charcoal, predominantly pine, but including red oak group and pecan 
depth of $4.65 \mathrm{ft}$ below present surface and $6 \mathrm{ft}$ below datum. Should be early in burial sequence and same as date for M-1268 (Michigan IX) at 3500 B.C.

\section{M-1265. Harris Creek midden}

$\mathbf{5 3 2 0} \pm \mathbf{2 0 0}$ 3370 в.с.

Charcoal from horizontal charcoal layer above burial zone, in Sq. 2A-3B at depth of 1 to $1.5 \mathrm{ft}$ below present surface and $3.5 \mathrm{ft}$ below datum. Should postdate burial sequence.

\section{M-1270. Harris Creek midden}

Shell (Busycon) tool in Sq. 2A-3B at depth of 3 to $4 \mathrm{ft}$ below surface and 6 to $7.5 \mathrm{ft}$ below datum.

General Comment (R.P.B.) : dates are all of same order of magnitude and the charcoal dates internally consistent. While shell date is 300 yr younger than charcoal dates, the $\Sigma$ overlap. Dates agree with typology of arrow points found with burials from other sites known to be preceramic. Burials were made between 3000 and 3500 B.c. or 1000 yr before introduction of fiber-tempered (Orange Plain) pottery. Ceremonial burial practices had an extremely early beginning in the Southeast. For preliminary report see Bullen (1961).

\section{M-1281. Daytona Beach, Florida}

Sea shells, Busycon perversum Linne (formerly Busycon carica eliceans) coll. near Daytona Beach $\left(29^{\circ} 25^{\prime} \mathrm{N}\right.$ Lat, $81^{\circ} 10^{\prime} \mathrm{W}$ Long $)$, Florida. Shells are recent, probably not more than $15 \mathrm{yr}$ since animals were living in them. Dated for comparison with those from Archaic Indian sites. Coll. 1961. Subm. by R. P. Bullen. Comment (R.P.B.) : something is wrong with either sample or dating.

\section{Northeastern United States and Canada}

\section{M-1502. Ram Pasture I site (M-52-31), $\quad 1010 \pm 100$ Massachusetts \\ A.D. 940}

Charred wood (No. C-1) from Ram Pasture I site $\left(41^{\circ} 16^{\prime} 31.5^{\prime \prime} \mathrm{N}\right.$ Lat, $70^{\circ} 08^{\prime} 12.25^{\prime \prime}$ W Long), Nantucket Is., Nantucket Co., Massachusetts. From charcoal-filled pit originating in subsoil at 8.5 in. below present surface, Sq. A 11, Sec. 1. Late Archaic component, Late Coastal Phase of Archaic pattern. Same level yielded side-notched points with straight or concave base; small trianguloid bi-excurvate points with concave base; ovate knives; plain gouges; ellipsoid bitruncate slate gorgets; no pottery. Estimated age ca. $3000 \mathrm{yr}$ ago. (For Woodland component at this site, see Stockley, 1964). Coll. 1962; subm. by B. H. Stockley, Shawkemo Chapter, Massachusetts Archaeol. Soc. Comment (B.H.S.) : date is surprisingly late for an Archaic manifestation, even considering possibility that high degree of cultural lag may be involved. Since Nantucket Island is separated from mainland by ca. $30 \mathrm{mi}$ of treacherous waters, some degree of cultural lag was not unexpected. No dates have previously been obtained on cultural materials from Nantucket Island, and since these materials differ in some respects from those found on mainland, there are no other $\mathrm{C}^{1+}$ dates which can confidently be used for direct comparison. Date must therefore be considered with suspicion unless confirmed by future tests. 


\section{Site DjRi-3 series, British Columbia, Canada}

Charcoal from Site DjRi-3 ( $49^{\circ} 33^{\prime}$ N Lat, $121^{\circ} 24^{\prime}$ W Long), British Columbia, in Frazer Canyon, ca. $110 \mathrm{mi}$ above its mouth, in Tait territory. Deeply stratified site with 4 earlier $\mathrm{C}^{14}$ dates ranging from $9000 \pm 150$ to $2360 \pm 60$ yr ago. Coll. 1961 by C. E. Borden. D. Rice, T. Denton, and D. McLeod; subm. for Borden by J. V. Wright, Natl. Mus. Canada.

$$
\text { M-1511. Site DjRi-3, Burial \# } \quad \begin{aligned}
570 & \pm 100
\end{aligned}
$$

Charcoal (NMC-9) covering Burial \# 7 in upper part (Zone A) of topsoil at S $6 \mathrm{ft} 5$ in. to $6 \mathrm{ft} 7 \mathrm{in}$. and $\mathrm{E} 17 \mathrm{ft}$ to $19 \mathrm{ft}$ from Datum A. Depth 29 to $32 \mathrm{in.}$ from surface, and 27 to $30 \mathrm{in}$. below Datum Plane A plus $2 \mathrm{ft}$. 19th century ethnographic information indicates Tait and adjacent Frazer Valley groups placed dead in mortuary houses. Burial \# 7, combining inhumation with partial cremation, seems to predate introduction of mortuary houses. Evidence from Frazer mouth indicates midden burial, customary on coast in millenium preceding our era, continued in following centuries, but was no longer practised by end of 13th century, possibly because of replacement by mortuary houses. If such houses subsequently spread to Tait area, date of Burial \#7 would be ca. $300 \pm 100 \mathrm{yr}$ ago. Alternatively, mortuary houses may have displaced inhumation earlier in the Tait area.

\section{M-1512. Site DjRi-3, Zone CO}

\section{B.c.} $7 \mathrm{in.} \mathrm{to} 18 \mathrm{ft} 11 \mathrm{in}$. E $6 \mathrm{ft}$ to $6 \mathrm{ft} 3 \mathrm{in}$. from Datum A, depth 56 to $59 \mathrm{in}$. from surface and 69 to $72 \mathrm{in}$. below Datum Plane A plus $2 \mathrm{ft}$. Near bottom of topsoil. Associated with earliest disc beads at site. Some carved steatite animal figurines occurred a few $\mathrm{ft}$ away. Though slightly higher, these appear to belong to same general period. Estimated age $2650 \pm 200 \mathrm{yr}$ ago, since ground slate completely absent from this level and those immediately above. Two previously dated samples (S-62 and S-112) associated with ground slate knives indicate that such implements were present in this part of Frazer Valley by 4th century B.C.

\section{M-1513. Site DjRi-3, Zone C}

$2800 \pm 130$

Charcoal (NMC-11) from bottom of Zone C in topsoil, at $\mathrm{S} 2$ to $4 \mathrm{ft}, \mathrm{F}$ 18 to $19 \mathrm{ft}$ from Datum A, depth 72 to $73 \mathrm{in}$. below surface and 68 to $69 \mathrm{in}$. below Datum Plane A plus $2 \mathrm{ft}$. From hearth area underlain by thin layer of yellow sand, which in turn rests directly on surface of gravel of Zone D. Should date occupation on top of gravel prior to or contemporary with beginning of deposition of $6 \mathrm{ft}$ of fine sandy loam which constitutes topsoil at site. Start of deposition of this fine, largely wind-blown, material may coincide with termination of Hypsithermal and beginning of modern climatic conditions which Heussey sets at ca. 1100 B.c. for SW British Columbia. Estimated age $2950 \pm$ $200 \mathrm{yr}$ ago.

General Comment (C.E.B.) : the A.D. 1380 date on Burial \# 7 suggests that disposal of dead in mortuary houses was adopted by Fraser Canyon groups at a later period and that the practice there is attributable to coastal influence. 
Nearly identical dates on M-1512 and M-1513 indicate that start of the deposition of the 6 to $7 \mathrm{ft}$ of topsoil (largely fine wind-blown material) at $\mathrm{DjRi}-3$ virtually coincides with termination of the Hypsithermal and beginning of modern climatic conditions which Heusser sets at ca. 1000 B.c. for SW British Columbia. Samples date a cultural complex which includes, inter alia, microblades and cores, burins, burin spall tools, drills, numerous disc beads, pendants, steatite rings, labrets, and small stone figurines, earliest-known sculpture from the Northwest. Phase appears to have persisted for some five centuries.

\section{M-1515. Pender Island Canal site (DeRt-2), $\quad 2200 \pm 120$ British Columbia, Canada \\ 250 в.C.}

Charcoal (NMC-13), from Pender Island Canal site, DeRt-2 (48 $45^{\prime} 50^{\prime \prime}$ N Lat, $123^{\circ} 15^{\prime} 20^{\prime \prime}$ W Long), British Columbia, on North Pender Is., Gulf of Georgia. From lowest of 3 levels in 2 nd test pit, depth $7 \mathrm{ft} 1$ in. below datum. Site is deeply stratified shell midden, ca. $400 \mathrm{yd}$ long by $20 \mathrm{yd}$ wide, 7 to $8 \mathrm{ft}$ deep. Bottom stratum associated with soapstone artifacts of Gulf Islands Complex, thought to be characteristic of Early Maritime (formerly "Eskimoid") culture of Gulf of Georgia area, described by Borden (1954). Culture known only from Locarno Beach site and lower levels of Whalen site, the former yielding dates of 2270 and $2430 \mathrm{yr}$ ago, and the latter $2450 \mathrm{yr}$ ago. May have centered in Gulf Islands. Canal site may be typical. Temporal position in Fraser delta uncertain, since dates bracketed by younger and older ones from Marpole phase in the same area. Dating of present sample from site in Islands may clear up confusion. Estimated age 2500 to $3000 \mathrm{yr}$ ago. See also Borden (1962), Duff (1955, 1956), and Kew (ms.). Coll. 1958 by J. E. M. Kew; subm. for William Duff by J. V. Wright. Comment (W.D.) : date reasonable; it adds to recent indications that both Early Maritime and especially Marpole phases are less ancient than formerly thought.

\section{Esilao (Site DjRi-5) series, British Columbia, Canada}

Charcoal samples from Esilao, Site DjRi-5 (45 $33^{\prime} \mathrm{N}$ Lat, $121^{\circ} 24^{\prime} \mathrm{W}$ Long). British Columbia, in Fraser Canyon ca. $110 \mathrm{mi}$ from mouth of Fraser R., in Tait Territory. Deeply stratified site. In 18th and 19th centuries was location of Esilao, pit house village of the Tait, easternmost division of the Coast 
M-1543 and approx. $2 \mathrm{ft}$ deeper, the strata being relatively horizontal. Though still rare, ground slate knives are present at this level.

\section{M-1545. Esilao, Site DjRi-5, Depth 146 to 148 in. \\ $4360 \pm 160$ \\ 2400 в.C.}

Charcoal (NMC-31) from S $30 \mathrm{ft} 6 \mathrm{in.}$, W $10 \mathrm{ft} 10 \mathrm{in.}$ Depth 146 to 148 in. from Datum Plane A. Hearth from which sample originated was 8 in. below bottom of a deep intrusive pit which extended $4.5 \mathrm{ft}$ downward from a more recent horizon at $84 \mathrm{in}$. beneath the datum plane. Though no ground slates were in immediate association with sample, partially-ground slate artifacts occur sporadically at this level ca. $20 \mathrm{ft}$ to the E.

\section{M-1546. Esilao, Site DjRi-5, Depth 180 in. $\quad 4880 \pm 180$ 2920 в.c.}

Charcoal (NMC-32) from S $25 \mathrm{ft}$ E $17 \mathrm{ft} 2 \mathrm{in.}$ Depth from Datum Plane A: $180 \mathrm{in.}$ (165 in. from surface). Coll. in deep test shaft some $28 \mathrm{ft} \mathrm{E}$ of location of M-1545 and ca. 32 in. deeper. Approx. $3 \mathrm{ft}$ below earliest ground slate.

\section{M-1547. Esilao, Site DjRi-5, Depth 225 in. $\quad 5490 \pm 500$}

Charcoal (NMC-33; small sample) from moist yellow (Navel at $\mathrm{S}$ moist yellow gravel at $\mathrm{S}$ ca. $26 \mathrm{ft} 5 \mathrm{in}$., E ca. $15 \mathrm{ft} 9$ in. Depth from Datum Plane A: 225 in. (213 in. from surface). Horizontal provenience similar to that of M-1546 but $45 \mathrm{in}$. deeper. A chipped stemmed projectile point was found just below spot from which sample was taken.

General Comment (C.E.B.) : original estimates on this series from Esilao too conservative. Reasonable age estimates are still difficult to arrive at in the Northwest because of paucity of dated cultural assemblages available for cross. dating.

Date of $2000 \pm 120$ on M-1543 may indicate that pit-houses have been in use in lower Fraser Valley since late in first millennium в.c. Measurements of other samples are needed before conclusion can be regarded as final. 
Dates on samples M-1544 to M-1547, ranging from latter half of third millennium to middle of fourth millennium B.c., are associated with cultural ass mblages which help fill the $4000 \mathrm{yr}$ gap that used to exist in our Fraser Canyon sequence. We now can trace a nearly continuous cultural development from earlier than 7000 B.c. to historic times.

\section{M-1526. Beswetherick site, Ontario, Canada \\ A.D. 1360

$$
590 \pm 100
$$

Wood charcoal (Temp. No. 66) from Beswetherick site (44. $23^{\prime} \mathrm{N}$ Lat, $79^{\circ} 43^{\prime}$ W Long), Ontario, in Lot 21, SW sec., Concession 8, Vespra Twp., Simcoe Co. From bottom of large pit at depth of $15 \mathrm{in}$. Site is only presently known component falling between Uren and Middleport substages of Ontario Iroquois Tradition. Sample should date this critical period. Estimated age A.D. 1350. Coll. 1963 by E. R. Channen; subm. for Channen by J. V. Wright. Comment (E.R.C.) : date substantiates method of age estimation by ceramic seriation in Iroquois studies.

\section{M-1527. Bennett site, Ontario Canada}

$670 \pm 100$

\section{A.D. 1280}

Wood charcoal (NMC-15) from Bennett site $\left(43^{\circ} 25^{\prime} \mathrm{N}\right.$ Lat, $79^{\circ} 57^{\prime} \mathrm{W}$ Long), Ontario, in Lot 14, Concession 1, Nelson Twp. Halton Co. From Pit 41 at depth of 40 in., directly under Burial B. Large palisaded pre-Uren site (Late Pickering Branch). Sample should act as check on GSC-143 date of $690 \pm$ 130 (GSC III, p. 180) and allow more accurate estimate of this critical period in development of Ontario Iroquois Tradition. Estimated age A.D. 1250. Coll. 1962. Subm. by J. V. Wright. Comment (J.V.W.) : close correlation of sample with $\mathrm{C}^{14}$ date from G.S.C. lab. and with seriational estimate, supports temporal placement of the site. Dates also support to accuracy of seriational estimates in Ontario Iroquois archaeology.

\section{$3390 \pm 140$}

Charcoal (NMC-25) from Sturdy Bay site $\left(48^{\circ} 47^{\prime} \mathrm{N}\right.$ Lat, $86^{\circ} 26^{\prime} \mathrm{W}$ Long), Ontario, on elevated beaches along $\mathbf{W}$ side of Sturdy Bay, Lake Superior approx. $4 \mathrm{mi} \mathrm{NW}$ of Marathon. From Hearth 1 at alt $40 \mathrm{ft}$ above lake level; coll. from basal portion of hearth at approx. depth of 6 in. Site represented by thin surface debris and occasional hearths occurring along 5 elevated beaches. Estimated age in excess of 2000 в.c. Coll. 1960. Subm. by J. V. Wright. Comment (J.V.W.) : as there are virtually no $\mathrm{C}^{14}$ estimates for the Shield Archaic in Northern Ontario date assists in placing one of the components of this widespread and little-known assemblage in time. It is of more direct value for estimating age of related sites in same general area at the $40-\mathrm{ft}$ beach elevation.

\section{M-1538. Roebuck site, Ontario, Canada}

$560 \pm 100$

Vegetal charcoal, primarily wood, but including some corn, beans, and cherry and plum pits (Temp. Nos. 301, 302,303), from the Roebuck site $\left(44^{\circ}\right.$ $49^{\prime} \mathrm{N}$ Lat, $75^{\circ} 36^{\prime} \mathrm{W}$ Long), Ontario, in Lots 2 and 3, Concession 6, Augusta Twp., Grenville Co. From 3 widely separated areas on site, all from undisturbed 
deposits, ash and midden, depths 8 to $24 \mathrm{in}$. Large palisaded Iroquois village excavated by Wintemberg in 1912 and 1915, classified by him as late prehistoric proto-Mohawk-Onondaga. MacNeish assesses it as late prehistoric Onondaga-Oneida, on basis of ceramics. Both recognize similarity with Hochelaga (Wintemberg, 1936; MacNeish, 1952). Estimated age A.D. 1500. Coll. 1963 by J. F. Pendergast and R. H. Grasely; subm. for Pendergast by J. V. Wright. Comment (J.F.P.) : date range established, 1290 to 1490 , introduces a new factor in eastern Ontario Iroquois archaeology. Should a 14thcentury date be correct, other sites in area which are judged to be earlier on basis of ceramics, would be put back into the mid-, or late, 13th-century period, on same time level as the $\mathrm{C}^{14}$-dated Bennett site, 1260 to 1290 . It would then have to be said that eastern Ontario Iroquois ceramics were infinitely superior in sophistication of shape, motif, and technique to the other Ontario Iroquois at that time. Since this seems unlikely, the 14th-century date is probably incorrect. The close mutual relationship observed between Roebuck and Hochelaga, visited by Cartier in 1534, favors instead a date in second half of 15th century.

\section{M-1539. Summerstown Station site, Ontario, Canada \\ $100 \pm 100$ A.D. 1850}

Carbonized corn kernels and cob (Temp. Nos. 501, 502) from Summerstown Station site $\left(45^{\circ} 05^{\prime} \mathrm{N}\right.$ Lat, $74^{\circ} 35^{\prime} \mathrm{W}$ Long $)$, Ontario, on Lot 12 , Concession 3, Charlottenburgh Twp., Glengarry Co. From different areas of site from black midden soil at depths of 8 to $10 \mathrm{in}$. below plow line. A large Iroquois village site noted by Wintemberg (1936) but not excavated until recently. Coll. 1963 by G. N. Gogo; subm. for J. F. Pendergast by J. V. Wright. Comment (J.F.P.) : date range established, 1750 to 1950 , is unacceptable. Site was probably occupied sometime between Roebuck (M-1538) and Salem (M-1541).

\section{M-1541. Salem site, Ontario, Canada}

Vegetal charcoal, primarily corn but including beans and cherry pits (Temp. No. 302) from Salem site $\left(45^{\circ} 04^{\prime} \mathrm{N}\right.$ Lat, $75^{\circ} 35^{\prime} \mathrm{W}$ Long), Ontario, in Lot 13, Concession 1, Front Charlottenburg Twp., Glengarry Co. From undisturbed midden of black soil from depth of between 8 to 24 in. Large Iroquois village site, same culture as Roebuck but earlier. Estimated age A.D. 1400 (Pendergast, 1964). Coll. 1963 by J. F. Pendergast and G. N. Gogo; subm. for Pendergast by J. V. Wright. Original view that site is somewhat earlier than Roebuck prevails.

\section{M-1552. Lawson site, Ontario, Canada $\quad 200 \pm 100$}

Carbonized corn and corn cob fragments (NMC-3) from Lawson site ( $43^{\circ} 4^{\prime} \mathrm{N} \mathrm{Lat}, 81^{\circ} 17^{\prime} \mathrm{W}$ Long), Ontario, in Lot 20, Concession 4, London Twp. Middlesex Co. From General digging, Midden 13. Prehistoric Neutral division of Neutral-Erie branch of Ontario Iroquois Tradition. Intended to date key site of Neutral division, and act as check on seriational estimates. Estimated date A.D. 1500. Coll. 1921 by W. J. Wintemberg; subm. by J. V. Wright. Comment (J.V.W.) : as site is prehistoric it is obvious that sample gave too late a reading. 
M-1553. Stafford site, Ontario, Canada

A.D. 1460

$490 \pm 100$

Carbonized corn and corn cobs (NMC-39) from Stafford site $\left(42^{\circ} 43^{\prime} \mathrm{N}\right.$ Lat, $80^{\circ} 47^{\prime} \mathrm{W}$ Long), Ontario, E-W center line, Lot 6 , Concession 4, Malahide Twp., Elgin Co. From Test Trench 4, extension F, depth 12 to 18 in. Glen Meyer Branch of Ontario Iroquois Tradition. Estimated age A.D. 1100 to 1200. Coll. 1951 by T. E. Lee; subm. by J. V. Wright. Comment (J.V.W.) : sample dated too late and seriational estimate is still regarded as approx. correct. Smallness of sample size may have been a factor in late date.

\section{Allumette Island-I site series, Quebec, Canada}

Charcoal from Allumette Island-1 site ( $45^{\circ} 49^{\prime} \mathrm{N}$ Lat, $77^{\circ} 01^{\prime} \mathrm{W}$ Long), Quebec, ca. $400 \mathrm{ft} \mathrm{N}$ of Lower Allumette (Westmeath) Lake (Ottawa R.), Lot 19, Concession 6, Ile Aux Allumettes, Pontiac Co. ca. 3 mi down river from Pembroke, Ontario. Site yielded 1012 copper artifacts, many distinctive of Old Copper culture. Estimated age 3000 to $5600 \mathrm{yr}$ ago, hased on dates from Riverside Cemetery, Michigan (M-658, Michigan III), and Oconto, Wisconsin (C836, Chicago V) (see Kennedy, 1963). Coll. 1963 by C. C. Kennedy and subm. for Kennedy by J. V. Wright.

\section{M-1548. Allumette Island-1 site, Hearth}

$3060 \pm 150$

1110 в.c.

Charcoal (NMC-34) from pit, apparently hearth, depth 7 to 13 in., latter being maximum depth of pit.

M-1549. Allumette Island-I site, Burial Pit

$1100 \pm 100$ A.D. 850

Charcoal (NMC-35) from burial pit fill, around bones of skeleton and from beneath them. Uppermost bones disturbed by plowing to depth of 6 to $7 \mathrm{in.} \mathrm{but} \mathrm{charcoal} \mathrm{apparently} \mathrm{in} \mathrm{situ.}$

General Comment (J.B.G.) : date for M-1549 is much too young for Old Copper association. Additional samples are needed to more accurately date late Archaic complex at site.

\section{E. Western United States}

\section{M-1424. Verde Valley, Arizona}

$125 \pm 100$

Cotton textile, perhaps from pueblo, Verde Valley, Arizona. Apparently from surface or shallow exposed pit. Coll. by Leon J. Cole (deceased) prior to 1928 and subm. by Gary Wright and James B. Griffin. Comment (G.W.) : date is disappointing, as one of approx. A.D. 1100 to 1325 had been expected. Preservation of cotton textile appears excellent, and discrepancy between expected and computed dates not explainable.

\section{F. Arctic}

\section{M-1504. Buchanan site, Northwest Territories, $\quad 2185 \pm 120$ Canada \\ 235 в.c.}

Raw antler, teeth, and bone (NMC-2) from Buchanan site $\left(69^{\circ} 24^{\prime} \mathrm{N}\right.$ Lat, $106^{\circ} 15^{\prime} \mathrm{W}$ Long), Northwest Territories, on Fergusson River on Victoria 
Is., $35 \mathrm{mi}$ NW of Cambridge Bay. From Test Cut No. 2, in moist dark brown humus layer at depth of 3 to $8 \mathrm{in}$. Layer produced burins, burin spalls, quartz crystal microblade, antler arrowhead, coarse quartzite tools, animal bone, antler fragments. Pre-Dorset assemblage from component which is outlier of Buchanan site proper, the latter being early Dorset. As this is one of few preDorset sites found in central Canadian Arctic, precise age assessment would further knowledge of the period of eastward spread of Arctic Small Tool Tradition. Estimated age 1500 to 2000 B.c. Coll. 1963 by W. E. Taylor; subm. for Taylor by J. V. Wright. Comment (W.E.T.) : date, well within early Dorset time span, not acceptable for the Buchanan site Pre-Dorset component since the area (southwestern Victoria Island) contains Dorset sites which, on typological grounds, are as old as or older than 235 B.c.

\section{Jackson site series, Northwest Territories, Canada}

Carbon and seal hide from Jackson site $\left(70^{\circ} 11^{\prime}\right.$ Lat, $124^{\circ} 44^{\prime} \mathrm{W}$ Long $)$, Northwest Territories, at Police Point, $5 \mathrm{mi} W$ of Cape Parry, S side of Amundsen Gulf. House ruin yielded pottery lamp with Barrow Curvilinear decoration. Dating will provide data on age of Barrow Curvilinear ceramic style in Cape Parry area, present easternmost occurrence. May also aid in determining time of Thule culture occupation of region. Estimated age A.D. 1200. Coll. 1963 by W. E. Taylor; subm. for Taylor by J. V. Wright.

\section{M-1508. Jackson site}

$1190 \pm 100$

\section{A.D. 760}

Carbon encrustation of inner and outer surfaces of large rim sherd with faint decoration in Barrow Curvilinear style, from floor of house ruin with Thule Culture inventory. Upper part of house mound removed by bulldozer, leaving 3 to $6 \mathrm{in}$. layer of cultural debris and dirt on floor.

\section{M-1509. Jackson site}

$1220 \pm 100$

Scraps of raw seal hide, from floor of house yielding M-1508.

General Comment (W.E.T.) : concurrence of these two dates suggests that the Jackson site was occupied ca. A.D. 745 and implies that no later than A.D. 850 a developed stage of Thule culture existed on $S$ coast of Amundsen Gulf far to $\mathrm{E}$ of the known Birnirk area. This would mean that Thule culture came into existence earlier than generally believed; that it evolved from early or middle Birnirk, not from the close of Birnirk ca. 900 A.D.; and that the Thule movement E from Alaska began earlier than we have thought. Alternatively one might suggest that Thule grew from terminal Birnirk but that Birnirk ended roughly around A.D. 700. A third possibility would be that Thule originated about the extreme NE coast of Alaska and spread W and E. In light of present knowledge, these three suggestions range from scarcely likely through unlikely to ludicrous. Not being prepared to discard these two dates at the moment, I hope their awkward squad of suggestions will underline the need for more dates on this temporal segment from the coasts between the two Capes Krusenstern. 


\section{Parcdon-Moctezuma series, Mexico}

Wood charcoal from Paredon-Moctezuma site ( $16^{\circ} 14^{\prime} \mathrm{N}$ Lat, $93^{\circ} 52^{\prime} \mathrm{W}$ Long), $12 \mathrm{~km} \mathrm{SW}$ of Tonalá, State of Chiapas, Mexico. From refuse midden in post-Classic layers. Coll. 1962 by Matthew Wallrath; subm. by Clifford Evans, Inst. of Andean Research.

\section{M-1467. Paredon-Moctezuma site}

Charcoal (IAR-B1) from depth of 320 to $340 \mathrm{~cm}$.

\section{M-1468. Paredon-Moctezuma site}

Charcoal (IAR-B2) from depth of 360 to $380 \mathrm{~cm}$.

\section{M-1469. Paredon-Moctezuma site}

Charcoal (IAR-B3) from depth of 460 to $480 \mathrm{~cm}$.

$$
\begin{array}{r}
610 \pm 100 \\
\text { A.D. } 1340
\end{array}
$$

A.D. 1190

$$
760 \pm 100
$$

$$
\text { A.D. } 1080
$$

General Comment (G. F. Ekholm) : results support general estimates of dating of site by sherd types, but latest date of A.D. 1340 would seem a bit too late, as it is associated with Tohil Plumbate pottery, of the Toltec Period, and this date falls into Aztec Period.

\section{M-1470. Palenque Island site (IS-3), Panama \\ $1190 \pm 100$ A.D. 760}

Charcoal (IAR-G4) from Palenque Island site $\left(8^{\circ} 10^{\prime} 40^{\prime \prime} \mathrm{N}\right.$ Lat, $82^{\circ} 14^{\prime}$ W Long), Bahía de Muertos, Chiriquí Province, Panama. From Pit No. 2, 90 to $100 \mathrm{~cm}$ level, in association with polychromes of Parita and Coclé style, Macaracas in Ladd's classification (Ladd, 1964), used also by Linares (1963,). Good cross-dating with polychrome styles of other parts of Panama. Coll. 1961 by C. R. McGimsey, Freeman Mobley, and Olga Linares; subm. by Clifford Evans. Comment (O.L.) : good agreement with sequence based on pottery. Falls at end of Burica Phase and therefore in correct order from latest to earliest as follows: Chiriqui Phase: $115 \pm 100$ B.P. (M-1309, Michigan IX) ; San Lorenzo Phase: $930 \pm 100$ B.P. (M-1308, Michigan IX); end of Burica Phase: $1190 \pm 100$ B.P.

\section{Site MO-1 series, Panama}

Charcoal from Site MO-1 ( $7^{\circ} 42^{\prime} 40^{\prime \prime} \mathrm{N}$ Lat, $81^{\circ} 2^{\prime} 20^{\prime \prime} \mathrm{W}$ Long), in Mariato region of $\mathrm{W}$ coast of Azuero Peninsula between mouth of Rio Suay and Rio Angulo, ca. $250 \mathrm{~m} \mathrm{E}$ of Montijo Bay and town of Diafara. From two stratified shell mounds, Mound 2 with total height of $410 \mathrm{~cm}$ and Mound 4 with total height of $260 \mathrm{~cm}$. Site believed occupied during Period IV extending into Period V as defined by Baudez (1963). Ceramics can be related to other sequences in Panama. Coll. 1962 by J. A. Schultz; subm. by Clifford Evans.

\section{M-1471. Site MO-1, Mound 2}

$1480 \pm 120$

$$
\text { A.D. } 470
$$

Charcoal (IAR-G6) from Mound 2, 190 to $205 \mathrm{~cm}$ below top of mound. 
M-1472. Site MO-1, Mound 2

$1700 \pm 120$

Charcoal (IAR-G7) from Mound 2, 355 to $370 \mathrm{~cm}$ below top of mound.

\section{M-1473. Site MO-1, Mound 4}

$1400 \pm 120$

Charcoal (IAR-G8) from Mound 4, 130 to $150 \mathrm{~cm}$ below top of mound.

\section{M-1474. Site MO-1, Mound 4}

$1760 \pm 130$

Charcoal (IAR-G9) from Mound 4, 215 to $225 \mathrm{~cm}$ below top of mound. General Comment (C.R.M.) : internally consistent and conform reasonably well to identification of associated materials in terms of Baudez's periods and his estimates of dates for them (Baudez, 1963).

\section{M-1202. Sambaqui de Forte Marechal Luz, Brazil

Charcoal from Sambaqui de Forte Marechal Luz $\left(27^{\circ} 50^{\prime} \mathrm{S}\right.$ Lat, $48^{\circ} 50^{\prime}$ W Long), Ilha de San Francisco, Santa Catarina, Brazil. From ceremonial "fireplace" over burial No. 5, Occupation Zone VI, in Stratum 4B. Provides date for first occurrence of pottery at the site. Coll. 1960 and subm. hy A. L. Bryan, Univ. of Alberta. Comment (A.L.B.) : date makes necessary reinterpretation of dates previously published (M-1200, 1203-1208, Michigan IX). M1203, from a charcoal lens originally assigned to Stratum 5, was apparently associated with two burials intruded from the top stratum. Hence dates are in proper order except for inconsistency between M-1202 and M-1205. Latter (A.D. 1100) dates Zone $\mathrm{V}$ just before introduction of pottery, former (A.D. 1070) provides date for first occurrence of pottery in Zone VI. Slight discrepancy is within statistical range of error of one $\Sigma$. Would now place introduction of bifacial percussion flaking technique at ca. A.D. 900 to 1000 and introduction of pottery-making at ca. A.D. 1100. Site abandoned sometime during first half of 14th century.

\section{M-1475. Mina de Oro site, Colombia}

$$
\begin{array}{r}
1490 \pm 100 \\
\text { A.D. } 460
\end{array}
$$

Charcoal (IAR-H9) from Mina de Oro site $\left(10^{\circ} 35^{\prime} 16^{\prime \prime} \mathrm{N} \mathrm{Lat,} 74^{\circ} 20^{\prime}\right.$ $10^{\prime \prime} \mathrm{W}$ Long), middle course of Rio Fundación, Cienaga Grande, State of Magdalena, Colombia. Depth $65 \mathrm{~cm}$ from surface. Coll. 1962 by C. Angulo V; subm. by Clifford Evans. Comment (C.A.V.) : date associated with sherd material closely related to Reichel-Dolmatoff's Saloa Phase of the Rio Magdalena (Reichel-Dolmatoff, 1954). Indicates approx. beginning of entrance of new group of peoples practising agriculture into Cienaga Grande area. Sterile overlying layer is related to late phases of Rio Magdalena, such as Plate Zambrano Phase.

\section{Lomo del Cuchal series, Colombia}

Charcoal from Loma del Cuchal $\left(10^{\circ} 35^{\prime} 10^{\prime \prime} \mathrm{N}\right.$ Lat, $74^{\circ} 20^{\prime} 12^{\prime \prime} \mathrm{W}$ Long), Rio Fundación, Cienaga Grande, Magdalena State, Colombia. Coll. 1962 by C. Angulo V.; subm. by Clifford Evans. 
M-1476. Loma del Cuchal Site

Charcoal (IAR-H10) from depth of $60 \mathrm{~cm}$ below surface.

\section{M-1477. Loma del Cuchal site}

Charcoal (IAR-H11) from depth of $80 \mathrm{~cm}$ below surface.

$$
\begin{array}{r}
1020 \\
\text { A.D. } 930
\end{array}
$$

General Comment (C.A.V.) : dates agree with estimates based on refuse. A.D. 930 marks end of Period I occupation for the area which also corresponds to the first phase at Mina de Oro Site. Date of A.D. 1230 marks approx. time of reoccupation of the site.

\section{Mataje series, Colombia}

Charcoal from Mataje site, Mound CHP-57 ( $1^{\circ} 32^{\prime} \mathrm{N}$ Lat, $78^{\circ} 3^{\prime} \mathrm{W}$ Long), at mouth of Quebrada La Rucia, Mataje River, Tumaco area, Colombia. Coll. 1962 by Gerardo Reichel-Dolmatoff; subm. by Clifford Evans.
M-1478. Mataje Mound CHP-57
$1940 \pm 130$
A.D. 10

Charcoal (IAR-I8) from depth of $1.52 \mathrm{~m}$ below surface. Dates end of Period II. 1 m-thick sterile layer between Periods II and III.

\section{M-1479. Mataje Mound CHP-57}

$2250 \pm 200$

350 в.с.

Charcoal (IAR-I9) from depth of $2.80 \mathrm{~m}$ below surface. Dates red-lipped ware of early part of Period II.

\section{M-1480. Mataje Mound CHP-57}

$$
2350 \pm 130
$$$$
450 \text { в.c. }
$$

Charcoal (IAR-I10) from depth of $3 \mathrm{~m}$ below surface. Dates end of Period I.

General Comment (G.R.D.) : dates agree with expectations. Of prime importance for correlation of Mesoamerican-derived cultures with the development in Inter-Andean Colombia: Calima, Quimbaya, San Agustin, and Jama-Coaque and Bahia sequence on $\mathrm{N}$ coast of Ecuador. Comment (C.E.) : dates fit into Regional Development Period.

\section{M-1481. Boca de Imbilí site, Colombia}

$950 \pm 150$

\section{A.D. 1000}

Charcoal (IAR-I11) from Boca de Imbilí, Mound CHP-62 $\left(1^{\circ} 36^{\prime} \mathrm{N}\right.$ Lat, $78^{\circ} 43^{\prime} \mathrm{W}$ Long), Quebrada Imbilí and Rio Mira, Tumaco area, Colombia. From Cut I, $60 \mathrm{~cm}$ below surface. Coll. 1962 by Gerardo Reichel-Dolmatoff; subm. by Clifford Evans. Comment (G.R.D.) : checks with estimates for incised pottery complexes of Pacific Coast of Colombia.

\section{Far East and Pacific}

\section{M-1555. Shaikhan Dheri site, West Parkistan}

$$
\begin{gathered}
1990 \pm 120 \\
40 \text { в.с. }
\end{gathered}
$$

Charred wood from Shaikhan Dheri site $\left(34^{\circ} 11^{\prime} \mathrm{N}\right.$ Lat, $71^{\circ} 44^{\prime} \mathrm{E}$ Long $)$, West Pakistan, near Charsada in Peshawar District, $20 \mathrm{mi}$ NE of Peshawar. Burned wooden beam from Stratum 2, second building phase from the top. From private chapel of Kushana period, later burned. Many Kushana coins in 
this stratum. Date of Kushana period in dispute. Site referred to, with aerial photograph, in Wheeler (1962). Coll. 1963 and subm. by A. H. Dani, Univ. of Peshawar. Comment (A.H.D.) : date tends to support view that Kushana coins belong in first rather than second century of our era.

\section{Ahu Akivi series, Easter Island}

Charcoal and charred human bone from Ahu Akivi $\left(27^{\circ} \mathrm{S} \mathrm{Lat,} 109^{\circ} \mathrm{W}\right.$ Long), Easter Island, ca. $3 \mathrm{mi} \mathrm{N}$ of village of Hangaroa and ca. 11/2 mi inland from W coast. Location known as Runaruna (Figueroa and Mulloy, 1960; Mulloy and Figueroa, 1961). Coll. 1960 and subm. by W. Mulloy, Univ. of Wyoming.

\section{M-1370. Ahu Akivi, north wing}

Wood charcoal from Ahu Akivi, $\mathrm{N}$ wing, lying directly under primary mantle; position in grid system N 033.7, W 016.5. Dates construction of first mantle.

\section{M-1371. Ahu Akivi, crematorium}

\section{A.D. 1600}

$$
350 \pm 100
$$

Charred human bone and wood charcoal from bottom of deposit in central cyst of southernmost crematorium behind central section of Ahu Akivi. Dates first manifestation of disposal of dead by cremation at Ahu Akivi.

\section{M-1374. Ahu Akivi, between crematorium and ahu wall \\ $580 \pm 100$

$$
\text { A.D. } 1370
$$

Charred human bone and some charcoal from Ahu Akivi, from area between $a h u$ wall and southernmost crematorium. From top of bone deposit in an area apparently used after crematorium was filled. Should represent one of last cremations at site and, with M-1371, should give an idea of duration of practice of cremation at Ahu Akivi.

General Comment (W.M.) : M-1370 fits precisely with others in stratigraphic sequence. M-1371 is also very close, even if M-1374 actually represents the first cremation activity. M-1374 is earlier than it should be; should not be earlier than M-1370. Material from between $a h u$ wall and outer wall of crematorium may represent very early material scooped out and over wall of crematorium to make room for later cremations. Earliest of later cremations would be those dated by M-1371. This may account for the fact that M-1371 dates some $75 \mathrm{yr}$ after M-1370, which should mark original construction of the ahu.

\section{M-1372. Ahu Vaiteka, Easter Island}

$330 \pm 100$

Wood charcoal from Ahu Vaiteka (270 S Lat, $109^{\circ} \mathrm{W}$ Long), Easter Island, ca. $3 \mathrm{mi} \mathrm{N}$ of village of Hangaroa and ca. $1 \mathrm{mi}$ inland from $\mathrm{W}$ coast. Approx. $700 \mathrm{~m}$ directly $\mathrm{W}$ of Ahu Akivi. From hearth ca. $20 \mathrm{~cm}$ deep and centered $90 \mathrm{~cm} \mathrm{NW}$ of center of circular stone-walled enclosure. Intended to provide minimum date for enclosure, a very unusual ahu feature, and test its temporal association with the $a h u$ itself (Figueroa and Mulloy. 1960; Mulloy and Figueroa, 1961). Coll. 1960 and subm. by W. Mulloy. Comment (W.M.) : date seems ca. $50 \mathrm{yr}$ late; but is close enough to dates for original construction 
of Ahu Vaiteka to answer the basic question of cultural association of the $a h u$ and the circular manavai-like construction in front of it.

\section{Africa and Old World}

\section{M-1551. Gebel Silsilah site, Egypt}

Charcoal (NMC-37) from Gebel Silsilah Locality III site $\left(24^{\circ} 28^{\prime} \mathrm{N}\right.$ Lat, $32^{\circ} 57^{\prime}$ E Long), Kom Ombe, Upper Egypt. Open-air site now in desert ca. $3 \mathrm{~km}$ from modern Nile. From bottom part of occupation layer in stratified site, formerly on edge of branch of Pleistocene Nile R., later covered with silt. From small area occupation floor in Sq. 14-J. Sample directly associated with "Sebekian," new prehistoric culture. Intended to give date for this culture and terminal date for earlier and different industry stratified below Sebekian but lacking charcoal or other datable material; also to test geological estimate of late silt deposition phase of Pleistocene Nile. Estimated age between 10,000 and 15,000 yr. Coll. 1963 by P. E. L. Smith; subm. for Smith by J. V. Wright. Comment (P.E.L.S.) : age is possible from both archaeologic and the geologic points of view, but since this particular industry (the Sebekian) has not yet been reported from elsewhere in Africa, it is not possible to make comparisons with other sites. Age obtained by Isotopes Inc. from charcoal same level of same site is 2000 yr younger (Smith, 1964).

\section{Cueva Reclau series, Spain}

Animal bone from Cueva Reclau $\left(42^{\circ} 09^{\prime} 30^{\prime \prime} \mathrm{N}\right.$ Lat, $6^{\circ} 26^{\prime} 10^{\prime \prime} \mathrm{W}$ Long), $1 \mathrm{~km}$ from Seriná, Gerona Province, Spain. Stratified site with following levels: Neolithic 0.0 to $1.0 \mathrm{~m}$; sterile 1.0 to $2.0 \mathrm{~m}$; Solutrean 2.0 to $3.20 \mathrm{~m}$; Perigordian 3.20 to $4.40 \mathrm{~m}$; Aurignacian $4.40 \mathrm{~m}$ to $5.50 \mathrm{~m}$ (Corominas, 1946 , 1949b, 1956; Pairo and Casajuana, 1950). Coll. 1940-1950 and subm. by J. M. Corominas, Banolas, Gerona, Spain.

M-1015. Cueva Reclau, Aurignacian level

Depth 4.60 to $4.80 \mathrm{~m}$.

\section{M-1016. Cueva Reclau, Aurignacian level}

Depth 4.80 to $5.0 \mathrm{~m}$.

\section{M-1020. Cueva Reclau, Aurignacian level}

Depth 2.0 to $3.20 \mathrm{~m}$. Animal bone from Aurignacian level, a yellow argillaceous deposit with stalagtites. Contains split-base and flattened-base punches, small Chatelperron points, strangulated blades, edge-retouched blades, bilaterally-retouched blades, perforated teeth.

\section{M-1017. Cueva Reclau, Perigordian level}

Depth 3.20 to $3.40 \mathrm{~m}$.

\section{M-1018. Cueva Reclau, Perigordian level}

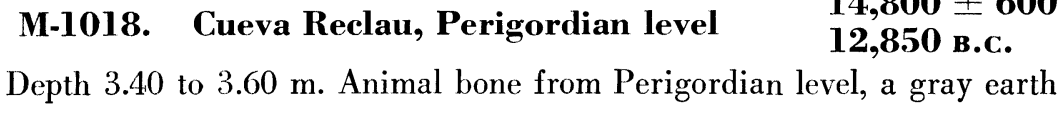

$16,560 \pm 600$ 14,610 в.с.

$18,700 \pm 800$ 16,750 в.с.

$16,200 \pm 500$ 14,250 в.c.
$14,750 \pm 600$ 12,800 в.с.

$14,800 \pm 600$ 
deposit with stalagtites. Abundant bones, La Gravette points, microliths, scrapers, atypical points, cylindrical punches.

\section{M-1019. Cueva Reclau, Solutrean level 11,250 в.C.}

Depth 2.0 to $3.20 \mathrm{~m}$. Animal bone from Solutrean level, a blackish argillaceous deposit with stalagtite fragments. Contains great quantities of animal bone, hearths, laurel and willow-leaf points assymetrically peduncled, protoSolutrean points, sharpened bones, perforated conch shells.

General Comment (J.B.C.) : publications on this cave should be consulted before using the dates.

\section{Cueva Encantades de Martis, Spain}

Bone from Cueva Encantades de Martis $\left(42^{\circ} 11^{\prime} \mathrm{N}\right.$ Lat, $6^{\circ} 28^{\prime} \mathrm{W}$ Long), municipal district of Esporellám, $8 \mathrm{~km}$ from Banolas, Gerona Province, Spain. Burial cave, without stratigraphic levels. Contained bones, ceramics, ornaments, and metals, representing Neolithic, Bronze, Hallstatt, and Iberic periods. Abundant human bone, a part of which is burned. Coll. 1940 to 1950 and subm. by J. M. Corominas.

\section{M-1021. Cueva Encantades de Martis, 3.0 to $\quad 3570 \pm 250$ $3.2 \mathrm{~m}$ level \\ 1620 B.C.}

Bone from 3.0 to $3.2 \mathrm{~m}$ level, associated with Eneolithic material.

\section{M-1022. Cueva Encantades de Martis, $1.20 \quad 4480 \pm 250$ to $1.40 \mathrm{~m}$ depth \\ 2530 в.C.}

Bone from 3.0 to $3.2 \mathrm{~m}$ level, associated with Bronze Age material. General Comment (J.B.G.) : dates probably indicate that site was badly disturbed in prehistoric times.

\section{M-1023. Cueva Bora Gran, Spain}

$$
\begin{aligned}
& 11,470 \pm 500 \\
& 9520 \text { в.с. }
\end{aligned}
$$

Bone from Cueva Bora Gran $\left(42^{\circ} 11^{\prime} \mathrm{N}\right.$ Lat, $6^{\circ} 26^{\prime} \mathrm{W}$ Long), $1 \mathrm{~km} \mathrm{~N}$ of Seriná, Gerona Province, Spain. Cave lacked stratification, but sample associated with Magdalenian industries IV, V, and VI (Corominas, 1949a). Coll. by L. Pericot and J. M. Corominas. Subm. by J. M. Corominas. Comment (J.B.G.) : date appears satisfactory.

\section{M-1523. Pihtipudas, Finland}

$$
\begin{aligned}
& 4750 \text { 土 } 180 \\
& 2800 \text { в.C. }
\end{aligned}
$$

LC-peat (Sample U10) from Pihtipudas (61 $28^{\prime}$ N Lat, $25^{\circ} 38^{\prime}$ E Long), Finland. Taken with piston bore from depth of $180 \mathrm{~cm}$. Pollen content of this level: Alnust $6 \%$, Betula $71 \%$, Pinus $21 \%$, Corylus $1 \%$, Ulmus $1 \%$. Sample should belong to Atlantic period ( $5500 \mathrm{yr}$ ). Related to change of outlet of Lake Paijanne from Gulf of Betthia $(\mathrm{N})$ to Gulf of Finland (S). Coll. 1963 and subm. by Risto Aario, Univ. of Helsinki. Comment (R.A.) : M-1523 agrees with pollen chronological age determinations and shows minimum age for shift in the channel of ancient Lake Päijänne (probably ca. 5000 to $6000 \mathrm{yr}$ ago ). 


\section{Lokanaapa Bog series, Finnish Lapland}

Peat and ooze taken with piston drill from Lokanaapa Bog $\left(67^{\circ} 50^{\prime} \mathrm{N}\right.$ Lat, $27^{\circ} 40^{\prime} \mathrm{E}$ Long), Sodankylä, Finnish Lapland, at ca. $241 \mathrm{~m}$ above sealevel. Coll. 1959 and subm. by Martti Salmi, Geol. Survey of Finland, Otaniemi.

\section{M-1559. Lokanaapa Bog, 3.75 to $3.85 \mathrm{~m}$ depth 7810 в.с.}

Carex-Equisetum peat with wood remains (sample 4) from 3.75 to $3.85 \mathrm{~m}$ depth. According to pollen analysis, it belongs to lower part of Betula period. Estimated age ca. 11,000 yr ago.

\section{M-1560. Lokanaapa Bog, 3.1 to $3.2 \mathrm{~m}$ depth $\quad \mathbf{8 5 0 0} \pm 300$}

Equisetum-Carex-Sphagnum peat (sample 5) from 3.1 to 3.2 depth. According to pollen analysis from upper part of Betula period. Estimated age ca. 8000 yr ago.

\section{M-1561. Lokanaapa Bog, 0.65 to 0.75 depth $\quad 3500 \pm 150$}

C Carex peat (sample 6) from 0.65 to $0.75 \mathrm{~m}$ depth. Accor to pollen analysis, vigorous spread of Picea began in area at that level. Estimated age ca. 3200 yr ago.

\section{Lammasvuoma Bog series, Finnish Lapland}

Peat and ooze taken with piston drill from Lammasvuoma Bog $\left(67^{\circ} 50^{\prime}\right.$ N Lat, $24^{\circ} 50^{\prime}$ E Long), Kittila, Finnish Lapland, at ca. $190 \mathrm{~m}$ above sealevel. Coll. 1963 and subm. by Martti Salmi.

\section{M-1562. Lammasvuoma Bog, 4.15 to $\quad 8390 \pm 350$ $4.25 \mathrm{~m}$ depth \\ 6440 в.C.}

Bryales-Equisetum allochontonous peat (sample 7) from the contact with coarse detritus ooze, from 4.15 to $4.25 \mathrm{~m}$ depth. According to pollen analysis, from lower part of Betula period. Estimated age ca. 10,500 yr ago.

M-1563. Lammasvuoma Bog, 3.55 to

$7890 \pm 400$ $3.65 \mathrm{~m}$ depth

5940 в.с.

Bryales-Sphagnum peat (sample 8) from 3.55 to $3.65 \mathrm{~m}$ depth. According to pollen analysis from $\mathrm{A}_{0}$ and upper part of Betula period. Estimated age ca. 8000 yr ago.

M-1564. Lammasvuoma Bog, 9.85 to

$3360 \pm 130$ $0.95 \mathrm{~m}$ depth

1410 в.c.

Carex-Bryales peat (sample 9) from 0.85 to $0.95 \mathrm{~m}$ depth. According to pollen analysis, vigorous spread of Picea began in area at that level. Estimated age ca. $3000 \mathrm{yr}$ ago.

\section{M-1565. Lake Mustajarvi, Finnish Lapland}

$10,700 \pm 500$

8850 в.c.

Three samples of pediastrum algae, lime ooze with fresh water mollusc shells, from same level of Lake Mustajarvi ( $67^{\circ} 40^{\prime} \mathrm{N}$ Lat, $25^{\circ} 15^{\prime} \mathrm{E}$ Long), near Kittila, Finnish Lapland at ca. $193 \mathrm{~m}$ above sealevel. Taken with piston drill from 8.30 to $8.35 \mathrm{~m}$ depth. According to pollen analysis, belongs to lower 
part of Betula period. Estimated age ca. 12,000 yr ago. Coll. 1963 and subm. by Martti Salmi.

\section{Teuraveuoma Bog series, Finnish Lapland}

Ooze and peat from Teuravuoma Bog $\left(67^{\circ} 20^{\prime} \mathrm{N}\right.$ Lat, $23^{\circ} 50^{\prime} \mathrm{E}$ Long), Kolari, Finnish Lapland, at ca. $160 \mathrm{~m}$ above sealevel. Taken with piston drill. Coll. 1963 and subm. by Martti Salmi.

\section{M-1566. Teuravuoma Bog, 2.10 to $2.13 \mathrm{~m}$ depth $7520 \pm 250$}

Detritus ooze (Sample 11) from contact with Bryales-Carex peat, from depth of 2.10 to $2.13 \mathrm{~m}$. According to pollen analysis, belongs to upper part of Betula period. Estimated age ca. $8000 \mathrm{yr}$ ago.

\section{M-1567. Teuravuoma Bog, 0.85 to $0.90 \mathrm{~m}$ depth $3550+150$}

Bryales-Carex peat (Sample 12) from depth of 0.85 to $0.90 \mathrm{~m}$. According to pollen analysis, vigrorous spread of Picea began in area at this level. Estimated age ca. 3100 yr ago.

General Comment (M.S.) : dates for ahove samples are satisfactory.

Date lists:

References

$\begin{array}{ll}\text { Chicago V } & \text { Libby, 1954 } \\ \text { GSC III } & \text { Dyck and Fyles, 1964 } \\ \text { Michigan I } & \text { Crane, 1956 } \\ \text { Michigan III } & \text { Crane and Griffin, 1958 } \\ \text { Michigan VI } & \text { Crane and Griffin, 1961 } \\ \text { Michigan VII } & \text { Crane and Griffin, 1962 } \\ \text { Michigan VIII } & \text { Crane and Griffin, 1963 } \\ \text { Michigan IX } & \text { Crane and Griffin, 1964 } \\ \text { USGS III } & \text { Rubin and Suess, 1956 }\end{array}$

Baudez, C., 1963, Cultural development in lower Central America: in Aboriginal Cultural Development in Latin America, an interpretive review: Smithsonian Misc. Coll., v. 146, no. 1 , p. $45-54$

Bell, R. E., 1949, Archaeological excavations at the Harlan Site, Fort Gibson Reservoir, Cherokee County, Oklahoma: Plains Archaeolog. Conference News Letter, v. 3, no. 1, p. 3-15.

Bettarel, R., and Harrison, S., 1962, An early ossuary in Michigan: Michigan Archaeol., v. 8 , no. 4 , p. 37.42

Binford, L. R., 1963, "Red Ochre" caches from the Michigan area: A possible case of cultural drift: Southwestern Jour. of Anthropol., v. 19, p. 89-108.

Borden, C. E., 1954, Some aspects of prehistoric coastal-interior relations in the northwest: Anthropol. in British Columbia, no. 4, p. 26-32.

1962, West coast crossties with Alaska; in Prehistoric cultural relations between the Arctic and Temperate Zones of North America, ed. by J. M. Campbell: Arctic Inst. of North Am. Tech. Paper, no. 11, p. 9-19.

Buck, A. I)., 1959, The Custer Focus of the southern plains: Oklahoma Anthropol. Soc. Bull., v. 7, p. 1-31.

Bullen, R. P., 1961, Radiocarbon dates for southeastern fiber-tempered pottery: Am. Antiquity, v. 10, p. 104-106.

1961b, Indian burials at Tick Island: Am. Philosoph. Soc. Yearbook, 1961, p. $477-480$.

Cleland, C. E., 1965, in press, Barren ground caribou, Rangifer articus, from an Early Man site in Southeastern Michigan: Am. Antiquity, v. 30, no. 3, p. 350-351.

Corominas, J. M., 1946, La cueva del Reclau-Viver de Serina: Anales del Instituto de Estudios Gerundenses, v. 1, p. 209.

1949a, La coleccion Corominas de la "Bora Gran": Consejo Superior de Investigaciones Cientificas, Materiales Prehistoricos de Serina, Monografias del Instituto de Fsudios Pirenaicos. 
1949b, El paleolitico superior en la Cueva Reclau-Viver de Serina (Espana): Rivista di Scienze Preistoriche, v. 4, p. 43.

1956. Las puntas de la Gravette en Serina: Cronica del Congreso Internat. de Ciencias Prehistoricas y Protohistoricas, 4th, Zaragosa, p. 189-194.

Crane, H. R., 1956, University of Michigan radiocarbon dates I: Science, v. 124, p. 664-672. 196la, The $\mathrm{CO}_{2-} \mathrm{CS}_{2}$ geiger counter and its use in C-14 dating (abstract):

Radiocarbon, v. 3, p. 6.

1961b, The $\mathrm{CO}_{2} \mathrm{CS}_{2}$ geiger counter: Rev. Sci. Instruments, v. 32, p. 953.

Crane, H. R., and Griffin, J. B., 1958, University of Michigan radiocarbon dates III: Science, v. 128, p. 1117-1123.

1961, University of Michigan radiocarbon dates VI: Radiocarbon, v. 3, p. 105 125. 204. 1962, University of Michigan radiocarbon dates VII: Radiocarbon, v. 4, p. 183204. 1963, University of Michigan radiocarbon dates VIII: Radiocarbon, v. 5, p. 228253.

1964, University of Michigan radiocarbon dates IX: Radiocarbon, v. 6, p. 1-25.

DeJarnette, D. L., Kurjack, E. B., and Cambron, J. W., 1962, Excavations at the StanfieldWorley Bluff Shelter: Jour. Alabama Archaeol., v. 8, nos. 1 \& 2.

Duff, Wilson, 1955a, Archaeological investigations at the Pender Island Canal Site: ms. in Provincial Mus. of British Columbia.

1955b, Unique stone artifacts from the Gulf Islands: Annal Report, Provincial Mus. of British Columbia, 1955, p. 45-55.

Dyck, W., and Fyles, J. G., 1964, Geological survey of Canada Radiocarbon dates III: Radiocarbon, v. 6, p. 165-181.

Farrand, W. R., 1960, Former shorelines in western and northern Lake Superior Basin; Ph.D. Thesis, Univ. of Michigan.

Figueroa, G., and Mulloy, W., 1960, Medidas a fin de salvar el tesoro arquelogico de la Isla de Pascua: Boletin de la Universidad de Chile, no. 14.

Fitting, J. E., 1964, Some characteristics of projectile point bases from Holcombe Site, Macomb County, Michigan: Papers of Michigan Acad. of Sci., Arts and Letters, v. 49, p. $231-238$.

1965, Late Woodland cultures of southeastern Michigan: Anthropol. Papers, Mus. of Anthropol., Univ. of Michigan, no. 24.

Foster, J. W., and Whitney, J. D., 1950, Report on the geology and topography of a portion of the Lake Superior Land District in the State of Michigan: Copper Lands, House Executive Documents, no. 69, pt. 1, 31st Congress, lst Session, Serials Document 578, Washington, D. C.

Griffin, J. B., 1961, Lake Superior copper and the Indians: Misc. Studies of Great Lakes Prehistory, Anthropol. Papers, Mus. of Anthropol., Univ. of Michigan, no. 17.

Hoare, R. D. et al., 1964, Pleistocene peccary Platygonus compressus LeConto from Sandusky County, Ohio: Ohio Jour. Sci., v. 64, no. 3, p. 207-214.

Hough, J. L., 1955, Lake Chippewa, a low stage of Lake Michigan indicated by bottom sediments: Geol Soc. Am. Bull., v. 66, p. 957-968.

1958, Geology of the Great Lakes: Urbana, Illinois, Univ. of Illinois Press.

Kennedy, C. C., 1963, The Allumette Island-1 (AL-1) Site: Field Report to Natl. Mus. of Canada, December 10, 1963.

Kew, J. F. M., n.d., Preliminary archaeological investigations at the Pender Island Canal Site: ms. at Provincial Mus. of Canada.

Ladd, J., 1964, Archaeological investigations in the Parita and Santa Maria zones of Panama: Bureau of Am. Ethnol., Bull. no. 193.

Libby, W. F., 1954, Chicago radiocarbon dates V: Science, v. 120, p. 733-742.

Linares de Sapir, O., 1963, Archaeological investigations in the Chiriqui Gulf area of Panama: Ph.D. thesis, Harvard Univ., to be published by Smithsonian Inst.

MacCurdy, H. M., 1919, Mastodon remains found in Gratiot County, Michigan: Michigan Acad.' Sci., 2lst Ann. Rept., p. 109-110.

MacNeish, R. S., 1952, Iroquois pottery types, a technique for the study of Iroquois prehistory: Natl. Mus. of Canada, Bull. no. 124, Anthropol. Series no. 31.

Maxwell, M. S., and Binford, L. H., 1961, Excavation at Fort Michilimackinac, Mackinac City, Michigan, 1959 Season: Pub. of the Mus., Michigan State Univ. Cultural Series, v. 1 , no. 1 .

McPherron, Alan, 1963, Late Woodland ceramics in the Straits of Mackinac: Papers of Michigan Acad. Sci., Arts and Letters, v. 48, p. 567-576.

Miller, J., 1963, Radiocarbon dates from Oklahoma and surrounding areas: Oklahoma Anthropol. Soc. Bull., v. 11, p. 115-121. 
Mulloy, W., and Figueroa, G., 1961, Como fue restorado el Ahu Akivi en la Isla de Pascua: Boletin de la Universidad de Chile, no. 27.

Oltz, D. F. Jr., and Kapp, R. O., 1963, Plant remains associated with mastodon and mammoth remains in central Michigan: Am. Midland Naturalist, v. 70, no. 2, p. 339-346.

Pairo, C., and Casajuana, T., 1950, Primer hallazgo del Leon de las Cavernas en el Pleistoceno de Cataluna: Pirineos, no. 17 \& 18, p. 521 .

Pendergast, J. F., 1964, Nine small sites on Lake St. Francis, Representing an early Iroquois Horizon in the Upper St. Lawrence River Valley: Anthrologica, v. 6, no. 2, p. 183-221.

Reichel-Dolomotoff, G., 1954, A preliminary study of space and time perspective in northern Columbia: Am. Antiquity, v. 19, no. 4, p. 352-366.

Rubin, M., and Suess, H. E., 1956, U. S. Geological Survey radiocarbon dates III: Science, v. 123 , p. $442-448$.

Skeels, M. A., 1962, The mastodons and mammoths of Michigan: Michigan Acad. Sci. Papers, v. 47, p. 101-133.

Smith, P. E. L., 1964, Radiocarbon dating of a Late Paleolithic culture from Egypt: Science, v. 145 , p. 811.

Stockley, B. H., 1964, Some unusual artifacts from Ram Pasture I, Nantucket, Massachusetts: Massachusetts Archeol. Soc. Bull., v. 25, no. $3 \& 4$.

Wheeler, R. E. M., 1962, Charsada, a metropolis of the Northwest Frontier, being a report on the excavations of 1958: pub. for Govt. of Pakistan and British Acad., Oxford Univ. Press.

Wilson, R., 1962, the A. W. Davis Site, Mc-6, of McCurtain County, Oklahoma: Oklahoma Anthropol. Soc. Bull., v. 10, p. 103-152.

Wintemberg, W. J., 1936, Roebuck prehistoric village site, Grenville County, Ontario: Natl. Mus. of Canada, Bull. no. 83, Anthropol. Series no. 31 .

Wright, H. T., 1964, A transitional Archaic campsite at Green Point (20 SA-1) : Michigan Archaeologist, v. 10, p. 17-22.

Wright, J. V., and Anderson, J. E., 1963, The Donaldson Site: Natl. Mus. of Canada, Bull. no. 184, Anthropol. Series no. 58.

Yarnell, R. A., 1964, Aboriginal relationships between culture and plant life in the Upper Great Lakes Area: Univ. of Michigan, Mus. of Anthropol., Anthropol. Papers, no. 23. 